\title{
The CPV "Toolbox": New Approaches to Maximizing Solar Resource Utilization with Application-Oriented Concentrator Photovoltaics
}

\author{
Harry Apostoleris ${ }^{1}$, Marco Stefancich ${ }^{2}$ and Matteo Chiesa 1,3,* \\ 1 Department of Mechanical Engineering, Khalifa University of Science \& Technology, \\ Abu Dhabi 127788, United Arab Emirates; harry.apostoleris@ku.ac.ae \\ 2 School of Engineering \& Applied Science, Rotterdam University of Applied Sciences, Blaak 10, \\ TA 3011 Rotterdam, The Netherlands; mstefancich@gmail.com \\ 3 Department of Physics \& Technology, UiT the Arctic University of Norway, 9010 Tromsø, Norway \\ * Correspondence: matteo.chiesa@uit.no
}

Citation: Apostoleris, H.; Stefancich, M.; Chiesa, M. The CPV “Toolbox": New Approaches to Maximizing Solar Resource Utilization with Application-Oriented Concentrator Photovoltaics. Energies 2021, 14, 795. https://doi.org/10.3390/en14040795

Academic Editor: I. M. Dharmadasa

Received: 4 January 2021

Accepted: 29 January 2021

Published: 3 February 2021

Publisher's Note: MDPI stays neutral with regard to jurisdictional claims in published maps and institutional affiliations.

Copyright: (c) 2021 by the authors. Licensee MDPI, Basel, Switzerland. This article is an open access article distributed under the terms and conditions of the Creative Commons Attribution (CC BY) license (https:// creativecommons.org/licenses/by/ $4.0 /)$.

\begin{abstract}
As the scaling of silicon PV cells and module manufacturing has driven solar energy penetration up and costs down, concentrator photovoltaic technologies, originally conceived as a cost-saving measure, have largely been left behind. The loss of market share by CPV is being locked in even as solar energy development encounters significant obstacles related to space constraints in many parts of the world. The inherently higher collection efficiency enabled by the use of concentrators could substantially alleviate these challenges, but the revival of CPV for this purpose requires substantial reinvention of the technology to actually capture the theoretically possible efficiency gains, and to do so at market-friendly costs. This article will discuss recent progress in key areas central to this reinvention, including miniaturization of cells and optics to produce compact, lightweight "micro-CPV" systems; hybridization of CPV with thermal, illumination and other applications to make use of unused energy streams such as diffuse light and waste heat; and the integration of sun-tracking into the $\mathrm{CPV}$ module architecture to enable greater light collection and more flexible deployment, including integration into built structures. Applications showing particular promise include thermal applications such as water heating, industrial processes and desalination; agricultural photovoltaics; building-integrated photovoltaics with dynamic daylighting capabilities; and chemical processes including photocatalysis and hydrogen production. By appropriately tailoring systems to the available solar resource and local energy demand, we demonstrate how CPV can finally achieve real-world efficiencies, or solar resource utilization factors, far higher than those of standard silicon-based PV systems. This makes the argument for sustained development of novel CPV designs that can be applied to the real-world settings where this efficiency boost will be most beneficial.
\end{abstract}

Keywords: concentrator photovoltaics; hybrid solar collectors; tracking integration; building integrated photovoltaics; agricultural photovoltaics; light splitting; photovoltaic-thermal systems

\section{Introduction: The Promise and Pitfalls of PV and CPV}

Keeping up with the rapid changes in the photovoltaics industry can be a full-time job for researchers in the solar energy field. While the drumbeat of new PV megaproject announcements and pricing records is constant and ever-increasing at the time of this writing [1], it is only five years previously that photovoltaics began to reach economic parity with conventional energy generation technologies on a global scale [2]. This rapid shift has appeared to spell the end of the road for one technology that was once believed to hold the key to widespread, low-cost solar energy adoption: concentrator photovoltaics (CPV).

The original cost-saving rationale for CPV has been discussed extensively [3], and until a decade ago still attracted significant investment and research focus within the still-immature field of photovoltaics. By shrinking the expensive photovoltaic cell and 
illuminating it with optics made from cheap commodity materials (glass or polymer), $\mathrm{CPV}$ for decades achieved lower module and per-kWh costs than non-concentrating solar panels based on large-area silicon PV cells. This was in spite of substantial additional costs imposed by the use of concentrators: the loss of all or most of the diffuse component of the solar resource; the requirement of a sun-tracking mechanism to maintain full-day illumination of the solar cells; and the need for passive or active cooling of the solar cells. However, CPV costs never declined sufficiently to compete with conventional energy generation, and it therefore remained only a big fish in the small pond of a stillniche solar market [4]. It was only the scaling of first silicon refining, and then cell and module manufacturing, and the associated learning-curve cost reductions, that allowed photovoltaics to first match, and now undercut in many places, the economics of the prevailing generation technologies [5-8].

As this transformation of solar energy economics took hold, CPV entered what could be described as a death spiral: pushing efficiency limits with increasingly highly-engineered multijunction solar cells; attempting to offset their harsh economics with higher concentration ratios; and finding these attempts at savings thwarted by a host of new costs in high-precision optics manufacturing and sun tracking, and losses imposed by the increasingly narrow angular acceptance profiles of these ultra-high concentration systems and stricter spectral-matching requirements of many-junction solar cells [9]. At the present time, efforts by conventional CPV manufacturers to salvage their business models appear to have roundly failed, and nearly all have declared bankruptcy or moved into other business areas.

There remains, in principle, one major selling point for $\mathrm{CPV}$, which is the capability for substantially higher efficiencies in the capture and conversion of sunlight. This is usually presented in economic terms, where high concentration factors enable the use of highefficiency solar cells with high manufacturing costs. However there is a fundamental aspect as well-concentrated light is of thermodynamically higher quality than unconcentrated light, as can be demonstrated, for example, by heating a working fluid under concentrated and unconcentrated light, and attempting to run a heat engine from each source. As a concentrating thermal collector can reach far higher temperatures than a non-concentrating collector, it can drive a higher-efficiency thermal process. Likewise, the efficiency limit for photovoltaic cells increases under concentrated light. Hence solar concentration potentially offers many pathways to extract more and better-quality energy outputs from the available solar resource. However, traditional CPV designs have and will continue to struggle to realize this higher efficiency in a way that is meaningful in real-world settings. In practice, doing so requires an understanding of the specific applications in which CPV systems are to be deployed, and in many cases a top-to-bottom redesign of the system to maximize applicability and collection of solar energy in its most useful forms.

This article seeks to make the case for a revival and total reimagining of concentrator photovoltaics, leveraging such previously experimental concepts as tracking integration, light splitting and heat recovery to utilize the full solar resource with double or triple the efficiency of current photovoltaics systems. We will discuss established and emerging applications for these technologies and implement simple performance models intended to give an indication of their potential. We aim for a shift in mindset from thinking about CPV as a specific technology to thinking of it as a "toolbox"-a suite of component technologies that can used and combined as needed to design optimized systems for specific, highvalue applications.

\section{Light-Splitting and Hybrid Solar Energy Collection}

A central concept in the design of application-oriented CPV systems is the division or splitting of the solar resource, which is illustrated in Figure 1. An important recognition is that even a conventional single-junction solar cell splits solar energy into different forms, although only the electrical output is typically utilized. In Figure 1a, this division of the solar spectrum is illustrated for an Alta Devices thin-film GaAs solar cell, the word record-holder for single junction photovoltaic efficiency [10]. The interaction of this 
type of cell with sunlight provides a clear illustration of the natural division of sunlight by a PV cell into converted, sub-bandgap and thermalized components. In addition to a high power conversion efficiency of $>28 \%$ on the AM1.5 spectrum [11], these highperformance cells have also been shown to have strong specular reflectance to sub-bandgap near-infrared photons $(\lambda>900 \mathrm{~nm})$ due to the use of a polished, highly reflective back contact [12]; roughly $40 \%$ of the incident solar energy is reflected, mostly in the near infrared. The remaining energy is dissipated as heat, which can be collected and used for low-temperature applications. In this way an appropriately-designed system based on these cells can capture solar energy with high efficiency, divided between three streamselectrical output, waste heat and the reflected NIR (the direct component of which can be concentrated for high-temperature applications as has been demonstrated elsewhere, achieving overall efficiencies of $48 \%$ [13]).
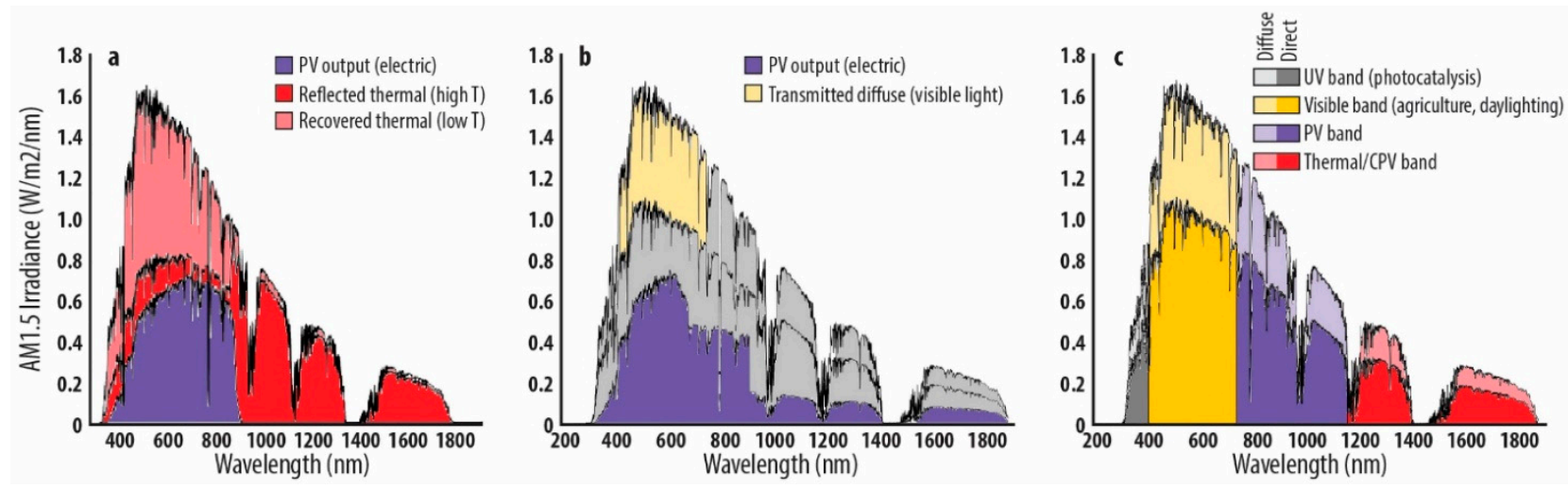

Figure 1. Solar resource splitting examples: (a) Dividing the solar resource between electricity, low-temperature heat and high-temperature heat using an optical concentrator including a silicon solar cell, a heat recovery system, a spectrumsplitting filter and a high-temperature thermal absorber; (b) Dividing solar energy between light \& electricity using a refractive concentrator; (c) "range of possibilities" for resource splitting, including UV for chemical/catalytic processes, visible band for agriculture \& daylighting, visible + short NIR for Si solar cells, all wavelengths for thermal applications, with distinction between direct (can be concentrated) and diffuse (minimal or no concentration).

Figure $1 \mathrm{~b}$ considers the division of the solar resource by conventional CPV. The plotted spectral conversion efficiency (SCE) curves are based on quantum efficiency [14] and subcell I-V characteristics [15] of Spectrolab's metamorphic III-V/Ge triple-junction CPV cell (Spectrolab, Sylmar, CA USA)), where

$$
\begin{gathered}
\operatorname{SCE}_{\text {subcell }}(\lambda)=\frac{1}{E_{\varphi}(\lambda)} Q E_{\text {subcell }}(\lambda) V_{O C_{\text {subcell }}} F F_{\text {subcell }} \\
\operatorname{SCE}_{\text {total }}(\lambda)=\sum_{\text {all subcells }} \operatorname{SC} E_{\text {subcell }}(\lambda)
\end{gathered}
$$

and where $E_{\varphi}(\lambda)$ is the photon energy at wavelength $\lambda$, and $Q E_{\text {subcell }}(\lambda), V_{O C_{\text {subcell }}}$ and $F F_{\text {subcell }}$ are the quantum efficiency, open-circuit voltage and fill factor, respectively, of the given subcell. The cell conversion efficiency on the direct component is $\sim 40 \%$, but the diffuse component is lost as it cannot be concentrated. However, diffuse light still represents a potentially valuable resource and can be captured with a straightforward modification of the module design. A growing trend is to design the CPV module to be transparent [16], allowing the diffuse component to be transmitted and used for illumination, as illustrated in Figure 2a,b. However, as this diffuse component cannot be efficiently transported (via optical fibers or light pipes), the module must be installed in the location where the diffuse light will be used. Hence issues of applicability in, for example, building-integrated settings, become particularly important to consider. 
a.

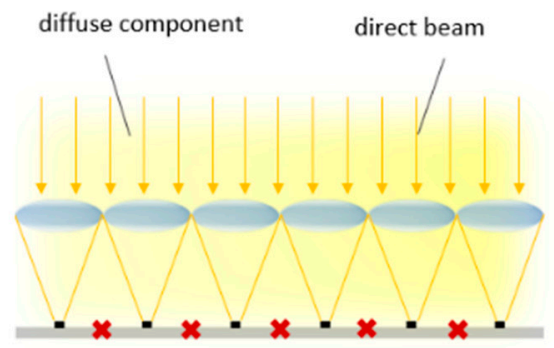

b.

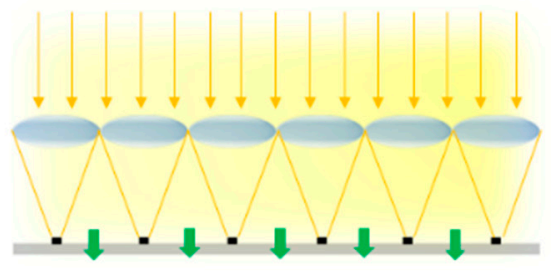

c.

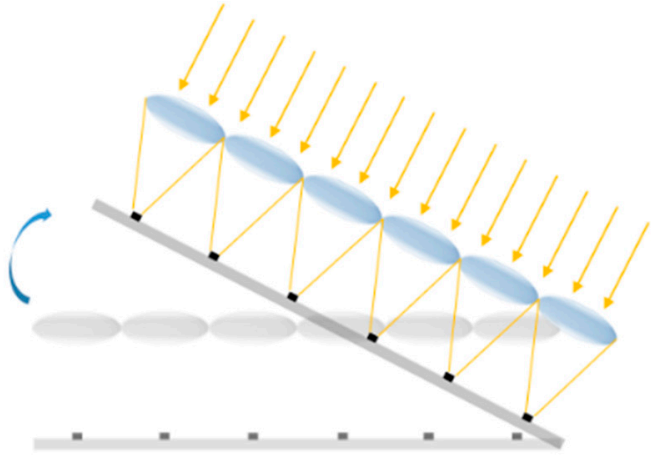

d.

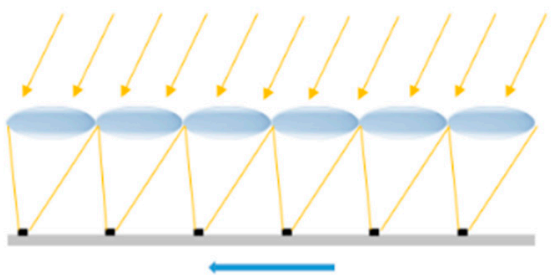

Figure 2. Contrast of conventional CPV with transparent, tracking-integrated CPV: (a) CPV cannot concentrate diffuse light and this component is lost; (b) in a transparent module, diffuse light passes through. (c) Conventional CPV tracks the sun by tilting the entire modules; (d) tracking-integrated CPV uses internal adjustments of the cells and optics, avoiding the need for an external sun-tracking device.

In Figure 1c a comprehensive schematic of the solar spectrum is displayed, broken into components denoted by which technologies or applications can effectively make use of them. Hence the spectral band from 400-1100 nm can be utilized by silicon photovoltaics; a wider band extending to $\sim 1800 \mathrm{~nm}$ can be captured by III-V/Ge multijunction cells, but due to their high cost these cells can only be used in practice in high-concentration systems (at least on Earth), and therefore can only access the direct portion of the spectrum. The entire solar spectrum can be used for thermal applications, but only the direct component can be concentrated to provide high-temperature heat. The visible band is useful for interior daylighting and indoor or greenhouse agriculture, and can significantly offset energy demand for artificial lighting for these applications. The ultraviolet, which is not efficiently converted by photovoltaic cells, can have value in chemical processes via the use of common photocatalysts, which respond strongly to the UV. The design of practical systems that facilitate the splitting of sunlight between multiple forms or end uses will be essential to realizing high efficiency capture of high-value solar energy.

\section{Micro-Concentrators and Micro-Tracking}

Restrictions on applicability, largely due to the requirement of sun tracking, have posed substantial limitations to the widespread adoption of CPV and present further challenges to the design of tailored application-oriented systems. A pair of developments, which are often combined with each other, promise to relax these restrictions if they can be successfully implemented in commercial products. Miniaturization of cells and optics to create micro-CPV systems [17] has gained popularity over the last decade as a way to create lightweight CPV systems with manageable form factors, while also minimizing cell heating and temperature uniformity by enabling better heat dissipation through the module back plate. Tracking integration [18] is a potentially game-changing concept which involves including the sun-tracking mechanism inside the CPV module, rather than mounting the module on an external tracker, conceptually illustrated in Figure 2c,d. In practice, these two concepts have typically been combined into "microtracking" CPV modules for integration into built structures. 
Various tracking integration schemes have been proposed and demonstrated for over a decade [19-25], mostly on experimental scales but with some recent commercial activity. Tracking integration provides an interesting study in the evolution of a concept through the past years' economic changes in PV and CPV. The concept of tracking integration began to attract attention as the prospects for conventional tracker-mounted CPV began to fade. As it became clear that CPV would be unable to compete with silicon technology for ground-mounted projects, tracking integration efforts initially sought to access the rooftop PV market, where the higher efficiency of CPV could add value. However, actually realizing this higher efficiency as higher energy output per unit area on a daily or yearly basis has proved challenging.

In order to fully take advantage of the high CPV efficiencies offered by multijunction cells, a tracking-integrated CPV module must optimize several factors that often compete: the concentration factor must be high enough to offset the cost of multijunction solar cells (typically $>400 \times$ ); the optical losses must not be high enough to offset the higher efficiency of the cells, generally implying that the optical system must be minimally complex with few surfaces; and the tracking range must be sufficient to capture sunlight over a wide range of incidence angles $\left( \pm 60^{\circ}\right.$ or more to approach the daily light collection performance of a non-concentrating module).

To date, the CPV design that has most fully achieved this multiple optimization was demonstrated by Price et al. in a mini-module consisting of a single optics-cell unit [26]. The optical system consisted of a single planoconvex lens above the cell and a concave mirror below; the combined refraction and reflection create a "bent" light path leading to a flat image plane, which allowed tracking over a range of $\pm 70^{\circ}$ to be accomplished by 2-dimensional lateral movements of the cell [27]. 30\% conversion efficiency of direct sunlight was achieved in outdoor testing. The demonstration model in this work was idealized in several key ways, including the use of high-index glass for the lens to push the concentration factor above $600 \times$, and the effective elimination of all but the first optical interface by the immersion of all internal layers in an index-matching fluid. A tracking-integrated module utilizing only refractive optics has been developed by the Swiss startup Insolight for commercial deployment and provides a benchmark for the performance that can feasibly be accomplished in a manufacturable tracking-integrated module. Characterizations have indicated a conversion efficiency of $27.5 \%$ at normal sunlight incidence in outdoor testing with a tracking range of roughly $\pm 55^{\circ}[28,29]$.

\section{Light-Splitting and Microtracking CPV: Predicting Performance and Application Potential}

\subsection{The Challenge of Rooftop CPV}

These experimental data allow a simple performance model to be implemented which illustrates the challenge of bringing "pure" CPV into the rooftop solar market, even with tracking integration. Here we show the results of a study in which the annual energy output of a rooftop CPV array is estimated based on data extracted from a standard rooftop PV simulation in NREL's System Advisor Model (SAM). The originally simulated system uses a $10 \mathrm{~kW}$ PV array based on $17 \%$ efficient SunPower modules, roughly the current average of commercial PV module efficiency [30]. For a yearlong hourly simulation, the diffuse and direct plane of array irradiance and solar incidence angle are extracted in addition to the array DC power output and used to estimate rooftop CPV power output based on the two experimentally-derived parameters of direct conversion efficiency and tracking range. This assumes a constant optical efficiency within the tracing range, which is a reasonable approximation of characterization results on real tracking-integrated CPV systems to date. The study is carried out for 22 locations around the world for which the direct fraction $f_{\text {dir }}$ (defined as the ratio of the direct POA irradiance to the total POA irradiance) ranging from $39 \%$ to $79 \%$. Only the upper part of this range is typically regarded as suitable for CPV. No impact of temperature is included, although experimental measurements are assumed to reflect the cells operating at $40-60{ }^{\circ} \mathrm{C}$ above ambient depending on the solar radiation strength, as shown by Price et al. [26]. It also seems likely that ambient temperature is less 
influential than for conventional PV modules if the cells are insulated on both sides by an air gap, which seems the most promising configuration for a mass-producible module. In Figure 3a the "CPV boost," or the ratio of the computed annual CPV output to the modeled PV array output, is plotted for both sample CPV systems: the "best case" system based on the work of Price [26,27], with $30 \%$ direct conversion efficiency within a $\pm 70^{\circ}$ range, and the "commercial" systems based on Insolight's model [28,29] with a $27.5 \%$ conversion efficiency and $\pm 55^{\circ}$ tracking range. The data are listed by location in Table 1. Even for the highest DNI locations, the "commercial" model outperforms average-efficiency PV modules by a factor of just $25 \%$. As high-efficiency modules with efficiencies above $20 \%$ more, which would reduce the CPV advantage to almost nothing, are readily available on the market for a modest premium, the argument for adopting rooftop CPV purely as an electricity-generating technology is unclear.
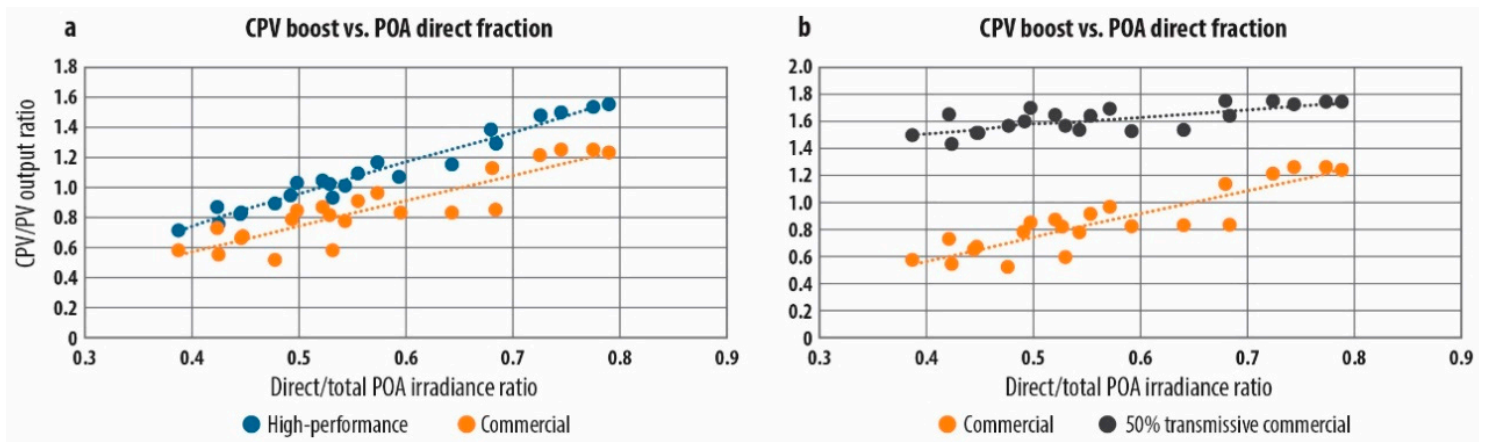

Figure 3. (a) Increase in annual solar resource utilization for two modeled tracking-integrated CPV modules: "commercial" module based on Insolight's THEIA technology [28,29] and "high-performance" module based on prototype of Price et al. [26,27]. "CPV boost" is ratio of annual energy outputs of CPV and reference modeled PV array (17\% efficiency). "POA direct fraction" is ratio of annual plane-of-array beam irradiance to total POA irradiance. Data correspond to Table 1. (b) CPV boost vs. direct fraction for the "commercial" non-transparent model and the same with $50 \%$ transparency to unconcentrated light.

Table 1. Summary of comparative performance simulations of TI-CPV and PV systems mounted at latitude tilt at 22 global locations, based on TMY weather files from the National Solar Resource Database. Both high and low DNI locations are included as indicated in the "direct fraction" column; direct fraction is the ratio of the annual beam POA irradiance to the total POA irradiance. The CPV boost is the ratio of the simulated annual CPV output to that of the reference silicon PV system. While the "commercial" CPV model provides only a modest boost in high DNI conditions, the semi-transparent CPV model offers a consistent boost of $50-75 \%$ across nearly all locations.

\begin{tabular}{|c|c|c|c|c|}
\hline Location & Direct Fraction & High-Performance CPV Boost & $\begin{array}{c}\text { Commercial CPV } \\
\text { Boost }\end{array}$ & $\begin{array}{c}50 \% \text { Transmissive Commercial } \\
\text { CPV Boost }\end{array}$ \\
\hline Buenos Aires & 0.53 & 0.94 & 0.59 & 1.58 \\
\hline Bogra & 0.50 & 1.03 & 0.86 & 1.70 \\
\hline Calgary & 0.64 & 1.15 & 0.83 & 1.55 \\
\hline Dagget & 0.79 & 1.56 & 1.24 & 1.74 \\
\hline Aswan & 0.74 & 1.51 & 1.26 & 1.74 \\
\hline Fargo & 0.59 & 1.08 & 0.83 & 1.53 \\
\hline Berlin & 0.44 & 0.83 & 0.66 & 1.53 \\
\hline Amapala Los Palonas & 0.68 & 1.39 & 1.14 & 1.76 \\
\hline Reykjavik & 0.42 & 0.76 & 0.55 & 1.45 \\
\hline Kagoshima & 0.49 & 0.96 & 0.79 & 1.60 \\
\hline Semipalatinsk & 0.54 & 1.02 & 0.79 & 1.55 \\
\hline Kaunas & 0.39 & 0.72 & 0.57 & 1.50 \\
\hline Macau & 0.52 & 1.04 & 0.87 & 1.65 \\
\hline Kathmandu & 0.57 & 1.16 & 0.96 & 1.70 \\
\hline Arequipa & 0.68 & 1.30 & 0.85 & 1.64 \\
\hline Kangnung & 0.53 & 1.01 & 0.82 & 1.58 \\
\hline Dakar & 0.55 & 1.10 & 0.92 & 1.64 \\
\hline Bangkok & 0.42 & 0.87 & 0.73 & 1.66 \\
\hline Kiev & 0.45 & 0.84 & 0.67 & 1.53 \\
\hline Tucson & 0.77 & 1.54 & 1.26 & 1.75 \\
\hline Abu Dhabi & 0.73 & 1.48 & 1.22 & 1.76 \\
\hline Harare & 0.48 & 0.89 & 0.51 & 1.58 \\
\hline
\end{tabular}


However, further incorporating the concept of hybridization changes the proposition significantly.

\subsection{Rooftop CPV with Partial Transparency: Adding Value from Unconcentrated Light}

Figure $3 \mathrm{~b}$ plots the boost in total solar resource utilization when the "commercial" module design is modified to transmit $50 \%$ of all unconcentrated light. The solar resource utilization is defined as the fraction of the available solar energy that is delivered to an end use in any form and can be defined formally as:

$$
S R U=\sum_{i} \frac{E_{i}}{S}
$$

where $E_{i}$ is the total energy in output stream $i$, and $S$ the total solar energy incident, during the time period of interest (in this case one year). In this example there are two output streams: electricity and transmitted radiation. If the transmitted stream is used for illumination or agriculture, only the visible portion of the spectrum $(400-700 \mathrm{~nm})$ counts towards the useful energy output. The calculations for Figure 3 assume the AM1.5 spectrum, for which visible light represents $43 \%$ of the total energy. In practice the transmitted spectrum will differ substantially from the solar spectrum and this should be considered rigorously in module design. In this configuration, the increase in total SRU relative to the reference PV systems can exceed $75 \%$. Interestingly, the dependence on the direct fraction is greatly reduced, since radiation that cannot be concentrated onto the cells instead passes through the module and is counted in the transmitted light stream.

It is worth briefly considering the transmitted component in the "natural" units of the two main target applications-building integration/illumination and agriculture. Illumination standards are typically given in lumens or lux $\left(\mathrm{lum} / \mathrm{m}^{2}\right)$; the conversion from irradiance to illuminance is spectrally dependent, but for standard solar spectra the conversion is typically taken as 90-100 lumens/W for direct sunlight and 110-120 lumens/W for the diffuse component, which is blue-shifted by atmospheric Rayleigh scattering [31]. For agriculture, the photosynthetically active radiation (PAR), which corresponds to the visible band, is measured in terms of photon flux $\left(\mathrm{mol} / \mathrm{m}^{2} / \mathrm{s}\right)$, and the main parameter impacting plant growth is the daily light integral (DLI), given in $\mathrm{mol} / \mathrm{m}^{2} /$ day [32]. In Figure 4 , the performance of a high-performance transmissive $\mathrm{CPV}$ module is modeled for the climates of Abu Dhabi and Boston, MA, USA using a simplified CPV performance model assuming $25 \%$ conversion efficiency of all direct light over the year and $70 \%$ transmission of all diffuse. The two locations are chosen to represent two interesting cases for CPV: a "dusty desert" climate with globally high DNI but also a significant diffuse component, stronger in the summer months, due to heavy scattering from atmospheric dust; and a temperate, mid-DNI climate in which CPV would not typically be used. The simulation is done for a south-facing system at latitude tilt. The transmitted component for each model is expressed in the average daily light integral. As would be expected, the Abu Dhabi system significantly outperforms the Boston system in terms of electricity production, owing to the stronger DNI resource and relative lack of cloud cover. However, the Boston system transmits more light year-round and especially during the summer days, when the days are long but frequent cloud cover still reduces the DNI resource significantly. This is consistent with the trend shown in Figure 3b, where the total solar resource utilization when both electrical output and light transmission are considered is much less dependent on the DNI fraction than the electrical output alone. The loss of electrical output in low DNI conditions tends to be compensated by increased light transmission. Hence, depending on the electricity and light requirements in a particular application setting, semi-transparent $\mathrm{CPV}$ can in principle find applicability in a much wider range of geographic location than pure CPV. In Figure 4b, the typical daily profiles for January and July of transmitted light

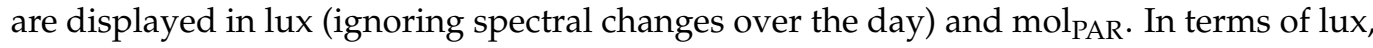
the transmitted illuminance mostly ranges from 10,000-20,000 lux. Given that standard guidelines recommend 500-1000 lux for most indoor activities, the transmitted light could 
in principle be sufficient to illuminate a floor area of perhaps 10 times the module area during daylight hours, or alternatively to light multiple stories of a commercial building. Hence a promising early application could be as skylights in residences or the atrium of a multistory building. Turning to an agricultural greenhouse application, PAR values throughout most of the year fall between $100-400 \mu \mathrm{mol} / \mathrm{m}^{2} / \mathrm{s}$, below the light saturation point for all but the lowest-light crops [33]. This indicates that the transmitted light will be fully utilized by most crops, but for higher-light crops significant additional lighting will be required. Another perspective on this is given in Figure 4c, where the cumulative daily light integrals for the two locations are plotted. The transmitted light alone is suitable for "low light" crops with DLI requirements of $<10 \mathrm{~mol} / \mathrm{m}^{2} /$ day. For moderate-light crops $\left(10-20 \mathrm{~mol} / \mathrm{m}^{2} /\right.$ day), the additional DLI can be partially supplied through greenhouse walls with appropriate design; in addition, the CPV module can in principle be operated to dynamically switch between energy production and additional light transmission, by defocusing the optics to transmit more light at times when energy demand is reduced.

a
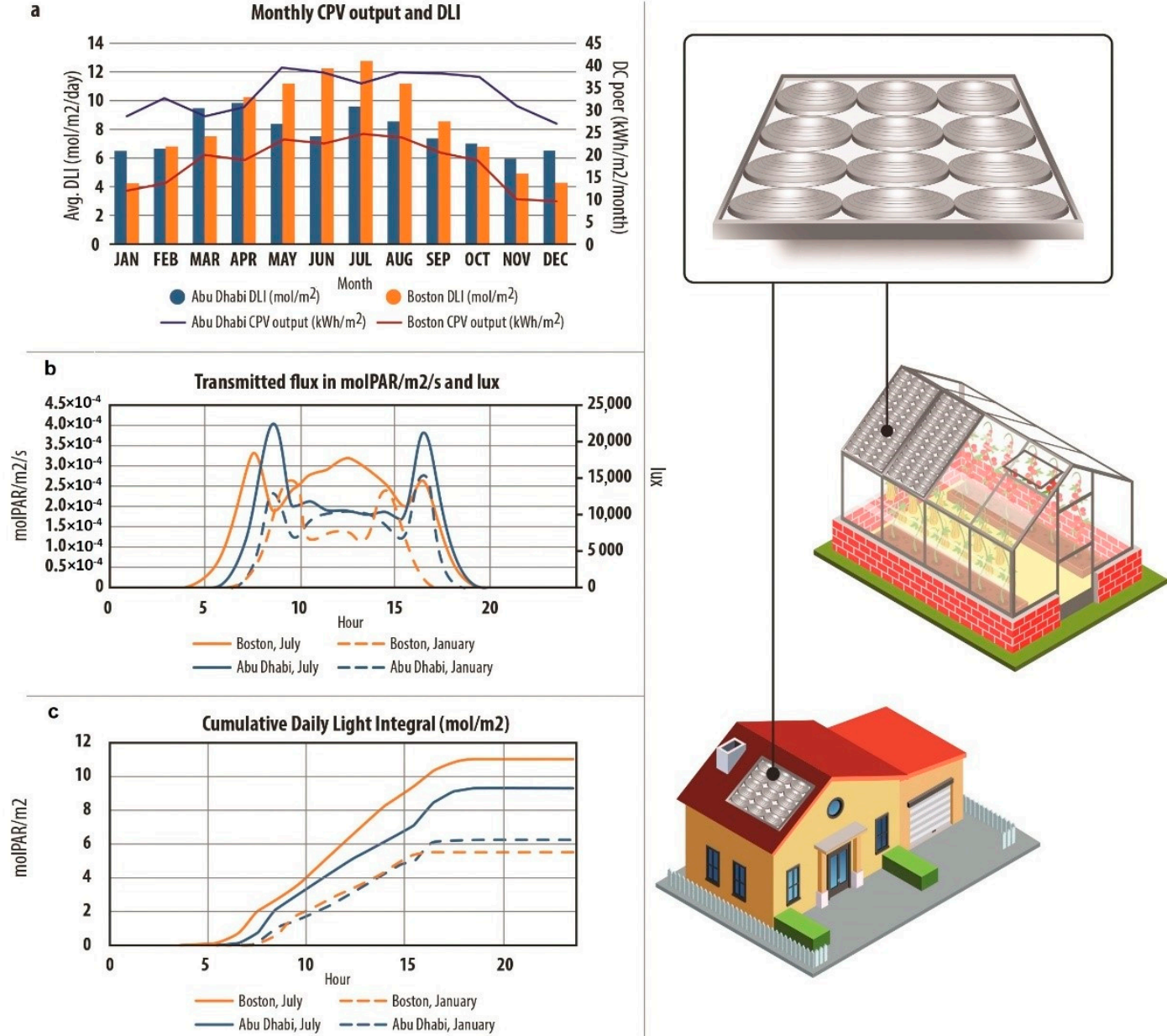

Figure 4. Transmission through described partially-transparent tracking-integrated CPV module (application concept right) in terms of (a) monthly average PAR daily light integral simulated in Boston (red) and Abu Dhabi (blue); (b) daily transmitted profile in terms of PAR (left axis) and lux (right axis) for July (solid line) and January (dashed line); (c) cumulative DLI for typical day in both locations in both months. Recommended indoor lighting levels are typically 1000 lux or less (direct sunlight is $\sim 100,000 \mathrm{lux}$ ). DLI of $<10 \mathrm{~mol} / \mathrm{m}^{2} /$ day are considered suitable for low-light crops [34]. On the right-hand side, applications concepts as skylights or in greenhouses. 


\subsection{Spectrum Splitting: New Applications for an Old Concept?}

The partially transparent CPV concept that has been discussed up to this point represents one form of light-splitting CPV. Another form of light-splitting that has a long history but has failed so far to find widespread commercial application in the solar energy field is spectral splitting. While in principle spectral splitting between multiple parallel PV cells can provide the efficiency of multijunction PV cells without the requirement of latticematching between the subcells $[35,36]$, in practice the cell technologies do not presently exist on a commercial scale that would make this approach economically favorable over multijunction cells. Spectrum-splitting PV-thermal collectors can reach high working fluid temperatures while retaining low cell temperatures by splitting the solar resource between a PV-optimized band and a thermal band [37]. Spectral splitting has been implemented with spectral filters [38,39], refractive and diffractive optics [40,41], and the use of the band gap of thin-film PV cells as a natural light splitter [42]. While all face economic challenges at this point, continued advances in nanofabrication and III-V device processing offer the possibility of changing this [43].

Some attention has been paid to spectral splitting or modification in the context of agricultural PV systems. As the incident light spectrum can have a significant on the growth of plants, e.g., by favoring flowering, fruiting or stem growth [44], some approaches to agricultural PV have considered the impacts of spectral filtering on crop growth [45]. Integrating pre-tailored spectral filtering, or the capability of dynamic spectral control, into agriculture-oriented CPV systems could be a fruitful area for future study.

Anther multi-stream spectral splitting concept could be the integration of PV and/or solar thermal collection with photocatalytic processes [46]. Photocatalysis has long been proposed as an environmentally friendly pathway to chemical production, and can be accomplished with the use of low-cost catalytic materials, most prominently $\mathrm{TiO}_{2}$ [47]. Due to the wide band gap of common photocatalysts, these processes operate with low efficiency on the fully solar spectrum, despite research efforts to broaden photocatalyst absorption beyond the UV [48]. However, combination with photovoltaics, which do not effectively convert the UV, or with solar thermal collection in a thermo-photocatalysis configuration [49], could present a feasible option for cost-effective and energy-efficient adoption of photocatalysis in the chemical industry.

\section{PV-Thermal Applications}

A second major class of CPV systems which employ hybridization to reach high levels of solar resource utilization are PV-thermal (PVT) systems in which waste heat is recovered from the solar cell and used for thermal applications. Non-concentrating PVT systems, essentially flat-plate collectors with PV cells integrated into the front side, are available on the market, although the temperatures that can be reached in this configuration are fairly low-the system obeying the same physical restraints as conventional flat-plate solar heat collectors [50,51]. The value of concentration is especially clear in boosting the temperature at which heat can be extracted from a PVT collector, opening up significant possibilities for concentrating "CPVT" systems [52,53]. Whereas the transmissive "power + light" systems discussed in the previous section are adaptations of high-concentration CPV designs, the most promising concentrating PVT concepts appear to be more inspired by solar thermal collectors, with PV cells integrated into the receiver [54].

It is worth considering theoretically the physical considerations in designing a PVT system. The two output streams are electricity and heat, where the heat is extracted from the solar cell during operation. In the evaluation of such a system it is helpful to consider the total exergy that can be extracted from the system. For the photovoltaic component, this is the electrical output. For the thermal output, this is the thermal collection efficiency multiplied by the Carnot factor of the output and ambient temperatures. The following brief analysis explores the upper limits of a CPVT systems based on heat recovery from a high-efficiency single-junction PV cell. All parameters for the PV cell are taken from characterizations of Alta Devices' record GaAs cell [10,55]. 
To perform this evaluation it is important to consider the dependence of PV cell efficiency on both concentration and temperature. Both arise from the logarithmic dependence of the $V_{O C}$ on the ratio of the photocurrent $I_{\varphi}$ to the saturation current $I_{0}$, or:

$$
V_{O C}=\frac{k T}{q} \ln \left(\frac{I_{\varphi}}{I_{0}}+1\right)
$$

where $I_{\varphi}$ is proportional to the illumination intensity and the temperature dependence, which arises from the $T$ dependence of $I_{0}$, leads to a linear dependence of $V_{O C}$ on temperature expressed in the temperature coefficient $k_{\mathrm{T}(\mathrm{Voc})}$. Combining with the weaker temperature dependences of ISC and fill factor gives the temperature coefficient of power $k_{\mathrm{T}(\mathrm{P})}$ which will be used throughout this analysis as $k_{T}$. The dependence on $T$ and $C$ is now expressed as:

$$
\eta_{P V}(T, C)=\eta_{P V}\left(T_{0}, 1\right) \ln \left(C \frac{I_{\varphi}}{I_{0}}+1\right)\left(1+k_{T}\left(T-T_{0}\right)\right)
$$

The total thermal energy collected is then:

$$
E_{T h}=\left(1-\eta_{P V}\right) \eta_{T h} S
$$

where $\eta_{T h}$ is the thermal collection efficiency, and the total exergy of the thermal stream is:

$$
X_{T h}=E_{T h} \frac{T-T_{a m b}}{T}
$$

Combining thermal and PV components, the total solar resource utilization factor is:

$$
S R U_{P V T}=\frac{E_{T h}+E_{P V}}{S}
$$

The contour plots in Figure 5 show the change in PV efficiency and the upper SRU limit for different values of the temperature coefficient $k_{T} \equiv k_{T(\mathrm{P})}$ of around $-0.4 \% /{ }^{\circ} \mathrm{C}$ are common for medium-efficiency PV cells. High-quality Si products such as Panasonic's HIT have reported values around $-0.25 \% /{ }^{\circ} \mathrm{C}$ [56], while Alta Devices' GaAs cells have $k_{T} \approx 0.1 \% /{ }^{\circ} \mathrm{C}$ [55]. Concentrations ranging from $1-100 \times$ are considered, as well as temperatures up to $225^{\circ} \mathrm{C}$. Each of these ranges corresponds to the performance of a class of deployed or proposed line-focus solar concentrators. "Etendue-squeezing" concentrators with dual-axis tracking have been proposed for thermal and chemical applications that can reach $100 \times$ concentration factors with a 1-degree acceptance angle [57]; $200-250{ }^{\circ} \mathrm{C}$ is the upper limit of the performance of low-concentration compound parabolic collector (CPC) modules that are currently in commercial production [58]. While this temperature range is seen as too high for PV cell operation, this is not necessarily the case as can be seen from the figure. While a PV cell with $k_{T}=-0.4$ will lose $40 \%$ of its nominal power output when its operating temperature is increased from 25 to $125^{\circ} \mathrm{C}$, this loss drops to $25 \%$ for $k_{T}=-0.25$ (achieved in "premium" Si PV products), and to just $10 \%$ if $k_{T}=-0.1$ as in thin-film GaAs products. Hence the adoption of higher-quality cells with lower temperature coefficients, always desirable for conventional PV system performance, takes on new appeal when the possible applications of PVT systems are considered. The combination of low- $k_{T}$ cells with higher-concentration optics raises the possibility of PVT systems seeing applications far beyond the commonly-discussed low-temperature processes such as water heating and thermal desalination [59,60]. If we consider that temperatures up to $200{ }^{\circ} \mathrm{C}$ might be accessible to the PVT system, with appropriately high-performance cells, a range of industrial processes could be fed by the thermal output stream. Of particular interest could be applications where both heat and electricity are required. One intriguing possibility would be high-temperature electrolysis, a hydrogen production technique in which steam rather than liquid water is split to form $\mathrm{O}_{2}$ and $\mathrm{H}_{2}$ [61]. The elevated temperature of the steam boosts the efficiency of the electrolysis process by lowering the effective energy 
barrier to water splitting [62]. This could be favorable if a source of "free" heat is available, which might be the case with a suitably economical PVT system [63]. Another possible application could be as a source of heat for carbon capture via amine scrubbing in industrial processes [64]. As many processes involve emissions from chemical reactions that are not mitigated by switching to low-carbon sources of energy, this represents a critical area for decarbonization that could be addressed by PVT by simultaneously providing the energy to drive processes and to capture process emissions.
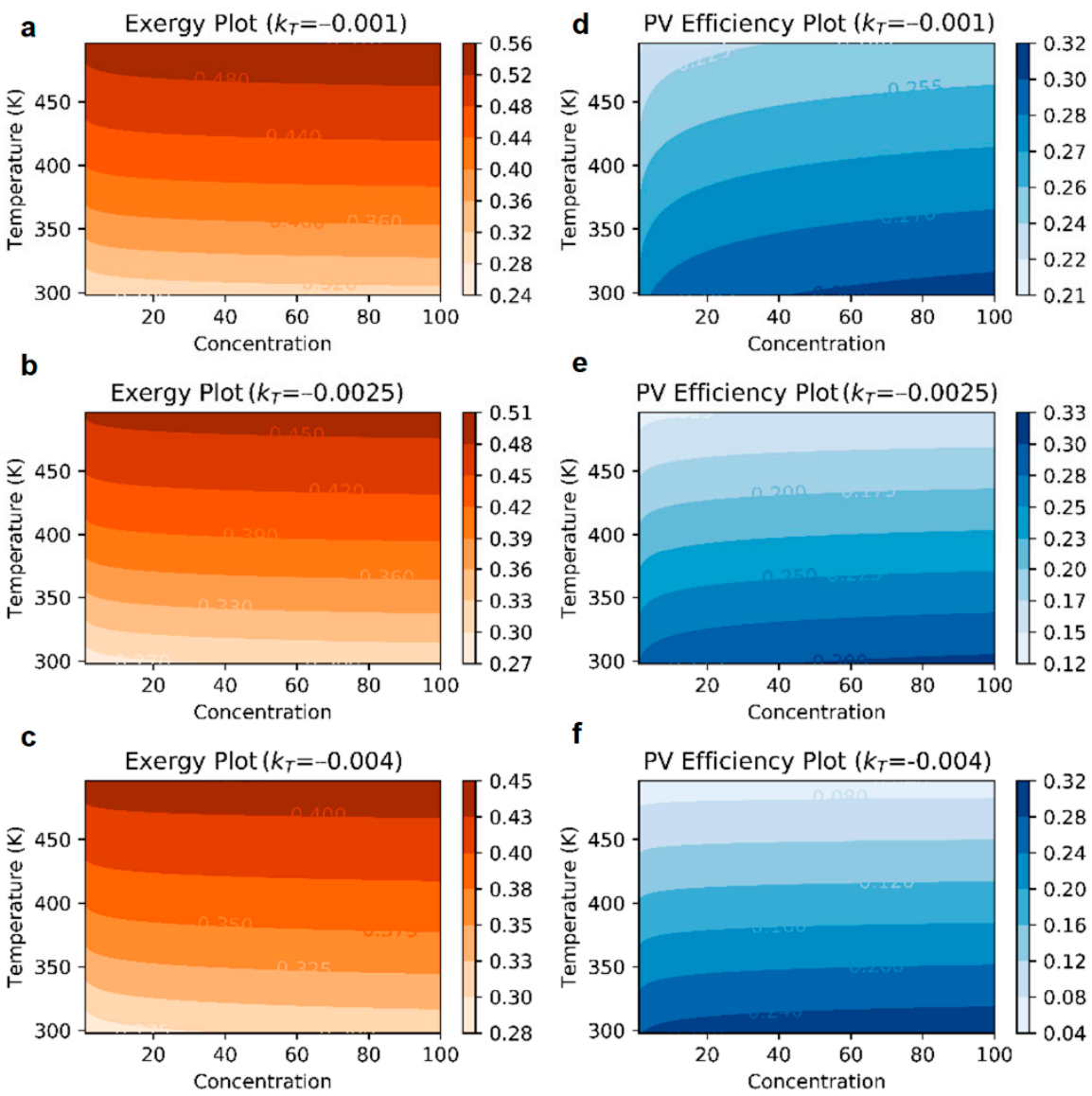

Figure 5. Upper-limit total exergy efficiency $(\mathbf{a}-\mathbf{c})$ and PV conversion efficiency $(\mathbf{d}-\mathbf{f})$ as a function of temperature \& concentration, for different values of $k_{T}\left(0.1 \% /{ }^{\circ} \mathrm{C}, 0.25 \% /{ }^{\circ} \mathrm{C}, 0.4 \% /{ }^{\circ} \mathrm{C}\right) \mathrm{PV}$ cell parameters based on Alta Devices record GaAs cell [10]. For $k_{T}=0.1 \% /{ }^{\circ} \mathrm{C}$, the PV cell efficiency remains above $20 \%$ up to $500 \mathrm{~K}$ from $28 \%$ at $300 \mathrm{~K}$, raising the possibility of high-temperature CPVT collectors.

\section{Remarks and Conclusions: A Future Path for CPV?}

If CPV has a future as a commercial solar technology, it will have to contend with an economic landscape vastly different that in which it was initially developed. CPV systems that add value over conventional PV will need to leverage the capability of concentrator systems to capture sunlight with high efficiency and to divide the solar resource between multiple output streams in different forms and for different applications. A "toolbox" of approaches to maximizing the applicability and performance of CPV systems can be identified that includes:

- Miniaturization of cells and optics to create micro-CPV modules with low mass, improved form factors and superior heat dissipation performance compared to conventional CPV designs;

- Integration of sun tracking into the module to enable fixed, trackerless installation; and 
- Development of hybrid collectors which capture parts of the solar resource that are unused by the PV cells as heat or light, boosting the overall solar resource utilization substantially.

We have surveyed established and emerging CPV designs relying on these concepts and identified two particular concepts as appearing to have significant future prospects: partially transparent tracking-integrated CPV for combined power generation and illumination in built structures; and concentrating photovoltaic-thermal systems with potential application to a range of industries, as well as water heating and desalination. The further development of high-performance PV cell technologies, including high-efficiency multijunction cells with lower production costs than the current standard, and cells with lower temperature coefficients for improved high-temperature performance. We implemented a number of simple models of overall system performance to provide general insight into the capabilities of these classes of system. In particular we demonstrate how currently realized designs of semi-transparent tracking-integrated CPV modules can be expected to provide a $50-75 \%$ boost in solar resource utilization relative to standard PV modules, when both the electrical output and transmitted visible light are accounted for; while PV-thermal systems can in principle reach SRU factors of $50 \%$ or more, counting electrical output and thermal exergy, if temperatures in the range of $200^{\circ} \mathrm{C}$ can be reached without unacceptable degradation of PV output. A number of emerging applications were considered, including agricultural photovoltaics, high temperature electrolysis for hydrogen production, and chemical production via photocatalytic processes, which could be particularly benefited by these next-generation CPV concepts. With commercial players already producing modules based on these concepts, it is now the time to move aggressively to identify which of these potential applications would see the most added value from a revival of CPV, and to press forward in the continued development, evaluation and optimization of these next-generation $\mathrm{CPV}$ technologies.

Author Contributions: Conceptualization, H.A, M.S. and M.C.; methodology H.A., M.S. and M.C.; formal analysis, H.A.; writing—original draft preparation, H.A.; writing—review and editing, M.S. \& M.C.; visualization, H.A.; supervision, M.C.; project administration, M.C. All authors have read and agreed to the published version of the manuscript.

Funding: This research received no external funding.

Institutional Review Board Statement: Not applicable.

Informed Consent Statement: Not applicable.

Data Availability Statement: Data available from the authors upon request.

Acknowledgments: The authors thank Maristsa Kissamitaki for her assistance in preparing the figures.

Conflicts of Interest: The authors declare no competing interest.

\section{References}

1. Apostoleris, H.; Sgouridis, S.; Stefancich, M.; Chiesa, M. Utility solar prices will continue to drop all over the world even without subsidies. Nat. Energy 2019, 4, 833-834. [CrossRef]

2. Shah, V.; Booream-Phelps, J. Crossing the Chasm Solar Grid Parity in a Low Oil Price Era; Deutsche Bank, February, 2015. Available online: https://www.db.com/cr/en/docs/solar_report_full_length.pdf (accessed on 2 February 2016).

3. Swanson, R.M. The promise of concentrators. Prog. Photovolt. Res. Appl. 2000, 8, 93-111. [CrossRef]

4. Wiesenfarth, M.; Philipps, S.; Bett, A.; Horowitz, K.; Kurtz, S. Current Status of Concentrator Photovoltaic (CPV) Technology V1.3; National Renewable Energy Laboratory (NREL): Golden, CO, USA, 2017. Available online: https:/ / www.ise.fraunhofer. $\mathrm{de} / \mathrm{de} /$ veroeffentlichungen/veroeffentlichungen-pdf-dateien/studien-und-konzeptpapiere/current-status-of-concentratorphotovoltaic-cpv-technology-in-englischer-sprache.pdf (accessed on 23 April 2018).

5. Green, M.A. How did solar cells get so cheap? Joule 2019, 3, 631-633. [CrossRef]

6. Kavlak, G.; McNerney, J.; Trancik, J.E. Evaluating the causes of cost reduction in photovoltaic modules. Energy Policy 2018, 123, 700-710. [CrossRef]

7. Swanson, R.M. A vision for crystalline silicon photovoltaics. Prog. Photovolt. Res. Appl. 2006, 14, 443-453. [CrossRef] 
8. Apostoleris, H.; Sgouridis, S.; Stefancich, M.; Chiesa, M. Evaluating the factors that led to low-priced solar electricity projects in the Middle East. Nat. Energy 2018, 3, 1. [CrossRef]

9. Apostoleris, H.C.; Stefancich, M.; Chiesa, M. Concentrating Photovoltaics (CPV): The Path Ahead (Green Energy and Technology); Springer International Publishing: Manhattan, NY, USA, 2018.

10. Kayes, B.M.; Nie, H.; Twist, R.; Spruytte, S.G.; Reinhardt, F.; Kizilyalli, I.C.; Higashi, G.S. 27.6\% Conversion efficiency, a new record for single-junction solar cells under 1 sun illumination. In Proceedings of the Photovoltaic Specialists Conference (PVSC), 37th IEEE, Seattle, WA, USA, 13 June 2011; pp. 000004-000008.

11. Green, M.A.; Emery, K.; Hishikawa, Y.; Warta, W.; Dunlop, E.D.; Levi, D.H.; Ho-Baillie, A.W.Y. Solar cell efficiency tables (version 49). Prog. Photovolt. Res. Appl. 2017, 25, 3-13. [CrossRef]

12. Winston, R.; Yablonovitch, E.; Jiang, L.; Widyolar, B.K.; Abdelhamid, M.; Scranton, G.; Cygan, D.; Kozlov, A. Hybrid solar collector using nonimaging optics and photovoltaic components. In Proceedings of the SPIE Optical Engineering+ Applications, San Diego, CA, USA, 9-13 August 2015; p. 957208.

13. Abdelhamid, M.; Widyolar, B.K.; Jiang, L.; Winston, R.; Yablonovitch, E.; Scranton, G.; Cygan, D.; Abbasi, H.; Kozlov, A. Novel double-stage high-concentrated solar hybrid photovoltaic/thermal (PV/T) collector with nonimaging optics and GaAs solar cells reflector. Appl. Energy 2016, 182, 68-79. [CrossRef]

14. Spectrolab. Datasheet: CPV Point Focus Solar Cells: C4MJ Metamorphic Fourth Generation CPV Technology. Available online: https:/ / www.spectrolab.com/DataSheets/PV/CPV/C3MJ_PLUS_2011.pdf (accessed on 12 December 2020).

15. Cotal, H.; Fetzer, C.; Boisvert, J.; Kinsey, G.; King, R.; Hebert, P.; Yoon, H.; Karam, N. III-V multijunction solar cells for concentrating photovoltaics. Energy Environ. Sci. 2009, 2, 174-192. [CrossRef]

16. Hirai, D.; Okamoto, K.; Yamada, N. Fabrication of highly transparent concentrator photovoltaic module for efficient dual land use in middle DNI region. In Proceedings of the 2015 IEEE 42nd Photovoltaic Specialist Conference (PVSC), New Orleans, LA, USA, 14-19 June 2015; pp. 1-4.

17. Domínguez, C.; Jost, N.; Askins, S.; Victoria, M.; Antón, I. A review of the promises and challenges of micro-concentrator photovoltaics. In AIP Conference Proceedings; American Institute of Physics: College Park, MD, USA, 2016 ; p. 080003.

18. Apostoleris, H.; Stefancich, M.; Chiesa, M. Tracking-integrated systems for concentrating photovoltaics. Nat. Energy 2016, 16018. [CrossRef]

19. Hallas, J.M.; Karp, J.H.; Tremblay, E.J.; Ford, J.E. Lateral Translation Micro-Tracking of Planar Micro-Optic Solar Concentrator. In SPIE Solar Energy+ Technology; International Society for Optics and Photonics: Bellingham, WA, USA, 2010; pp. 776904-776907.

20. Baker, K.A.; Karp, J.H.; Tremblay, E.J.; Hallas, J.M.; Ford, J.E. Reactive self-tracking solar concentrators: Concept, design, and initial materials characterization. Appl. Opt. 2012, 51, 1086-1094. [CrossRef]

21. Zagolla, V.; Tremblay, E.; Moser, C. Proof of principle demonstration of a self-tracking concentrator. Opt. Express 2014, 22, A498-A510. [CrossRef]

22. Cheng, J.; Park, S.; Chen, C.-L. Optofluidic solar concentrators using electrowetting tracking: Concept, design, and characterization. Sol. Energy 2013, 89, 152-161. [CrossRef]

23. Apostoleris, H.; Stefancich, M.; Lilliu, S.; Chiesa, M. Sun-tracking optical element realized using thermally activated transparencyswitching material. Opt. Express 2015, 23, A930-A935. [CrossRef]

24. Johnsen, H.J.; Torgersen, J.; Aksnes, A. Solar Tracking Using Beam-Steering Lens Arrays. In Nonimaging Optics: Efficient Design for Illumination and Solar Concentration XV; International Society for Optics and Photonics: Bellingham, WA, USA, 2018; Volume 10758, p. 1075805.

25. Teng, T.-C.; Kuo, C.-H.; Li, Y.-J. Planar solar concentrator composed of stacked waveguides with arc-segment structures and movable receiving assemblies. Opt. Express 2020, 28, 34362-34377. [CrossRef]

26. Price, J.S.; Grede, A.J.; Wang, B.; Lipski, M.V.; Fisher, B.; Lee, K.-T.; He, J.; Brulo, G.S.; Ma, X.; Burroughs, S. High-concentration planar microtracking photovoltaic system exceeding 30\% efficiency. Nat. Energy 2017, 2, 17113. [CrossRef]

27. Price, J.S.; Sheng, X.; Meulblok, B.M.; Rogers, J.A.; Giebink, N.C. Wide-angle planar microtracking for quasi-static microcell concentrating photovoltaics. Nat. Commun. 2015, 6. [CrossRef]

28. Nardin, G.; Domínguez, C.; Aguilar, Á.F.; Anglade, L.; Duchemin, M.; Schuppisser, D.; Gerlich, F.; Ackermann, M.; Coulot, L.; Cuénod, B. Industrialization of hybrid Si/III-V and translucent planar micro-tracking modules. Prog. Photovolt. Res. Appl. 2020. [CrossRef]

29. Askins, S.; Jost, N.; Aguilar, A.; Anglade, L.; Nardin, G.; Duchemin, M.; Gerlich, F.; Ackerman, M.; Coulot, L.; Petri, D. Performance of Hybrid Micro-Concentrator Module with Integrated Planar Tracking and Diffuse Light Collection. In Proceedings of the 2019 IEEE 46th Photovoltaic Specialists Conference (PVSC), Chicago, IL, USA, 16-21 June 2019; pp. 2507-2512.

30. Barbose, G.L.; Darghouth, N.R. Tracking the Sun IX: The Installed Price of Residential and Non-residential Photovalic Systems in the United States (Washington: US Department of Energy, 2016). Available Emp. Lbl. Gov. Publ. Trackin 2016. [CrossRef]

31. Littlefair, P.J. The luminous efficacy of daylight: A review. Lighting Res. Technol. 1985, 17, 162-182. [CrossRef]

32. Inada, K. Action spectra for photosynthesis in higher plants. Plant Cell Physiol. 1976, 17, 355-365.

33. Song, X.P.; Tan, H.T.; Tan, P.Y. Assessment of light adequacy for vertical farming in a tropical city. Urban For. Urban Green. 2018, 29, 49-57. [CrossRef]

34. Apostoleris, H.; Chiesa, M. High-concentration photovoltaics for dual-use with agriculture. In AIP Conference Proceedings; American Institute of Physics: College Park, MD, USA, 2019; p. 050002. 
35. Maragliano, C.; Apostoleris, H.; Bronzoni, M.; Rampino, S.; Stefancich, M.; Chiesa, M. Efficiency enhancement in two-cell CIGS photovoltaic system with low-cost optical spectral splitter. Opt. Express 2016, 24, A222-A233. [CrossRef]

36. Keevers, M.J.; Lau, C.F.J.; Green, M.A.; Thomas, I.; Lasich, J.B.; King, R.R.; Emery, K.A. High Efficiency Spectrum Splitting Prototype Submodule Using Commercial CPV Cells. Prog. Photovolt. Res. Appl. 2015. [CrossRef]

37. Crisostomo, F.; Taylor, R.A.; Surjadi, D.; Mojiri, A.; Rosengarten, G.; Hawkes, E.R. Spectral splitting strategy and optical model for the development of a concentrating hybrid PV/T collector. Appl. Energy 2015, 141, 238-246. [CrossRef]

38. Goetzberger, A.; Goldschmidt, J.; Peters, M.; Löper, P. Light trapping, a new approach to spectrum splitting. Sol. Energy Mater. Sol. Cells 2008, 92, 1570-1578. [CrossRef]

39. Kosten, E.D.; Warmann, E.C.; Lloyd, J.; Atwater, H.A. Spectrum splitting photovoltaics: Light trapping filtered concentrator for ultrahigh photovoltaic efficiency. In Proceedings of the SPIE Solar Energy+ Technology, San Diego, CA, USA, 26-29 August 2013; pp. 882109-1-882109-3.

40. Escarra, M.D.; Darbe, S.; Warmann, E.C.; Atwater, H. Spectrum-splitting photovoltaics: Holographic spectrum splitting in eight-junction, ultra-high efficiency module. In Proceedings of the 2013 IEEE 39th Photovoltaic Specialists Conference (PVSC), Tampa, FL, USA, 16-21 June 2013; pp. 1852-1855.

41. Stefancich, M.; Zayan, A.; Chiesa, M.; Rampino, S.; Roncati, D.; Kimerling, L.; Michel, J. Single element spectral splitting solar concentrator for multiple cells CPV system. Opt. Express 2012, 20, 9004-9018. [CrossRef]

42. Widyolar, B.; Jiang, L.; Ferry, J.; Winston, R.; Kirk, A.; Osowski, M.; Cygan, D.; Abbasi, H. Theoretical and experimental performance of a two-stage (50X) hybrid spectrum splitting solar collector tested to $600{ }^{\circ} \mathrm{C}$. Appl. Energy 2019, 239, 514-525. [CrossRef]

43. Kim, Y.; Cruz, S.S.; Lee, K.; Alawode, B.O.; Choi, C.; Song, Y.; Johnson, J.M.; Heidelberger, C.; Kong, W.; Choi, S. Remote epitaxy through graphene enables two-dimensional material-based layer transfer. Nature 2017, 544, 340-343. [CrossRef]

44. Meinen, E.; van Ieperen, W.; Hogewoning, S.; Trouwborst, G. Finding the Optimal Growth-Light Spectrum for Greenhouse Crops. In Proceedings of the VII International Symposium on Light in Horticultural Systems 956, Wageningen, The Netherlands, 12-25 October 2012; pp. 357-363.

45. Liu, W.; Liu, L.; Guan, C.; Zhang, F.; Li, M.; Lv, H.; Yao, P.; Ingenhoff, J. A novel agricultural photovoltaic system based on solar spectrum separation. Sol. Energy 2018, 162, 84-94. [CrossRef]

46. Hashemi, S.M.H.; Choi, J.-W.; Psaltis, D. Solar thermal harvesting for enhanced photocatalytic reactions. Phys. Chem. Chem. Phys. 2014, 16, 5137-5141. [CrossRef]

47. Nakata, K.; Fujishima, A. TiO2 photocatalysis: Design and applications. J. Photochem. Photobiol. C Photochem. Rev. 2012, 13, 169-189. [CrossRef]

48. Ozer, L.Y.; Apostoleris, H.; Ravaux, F.; Shylin, S.I.; Mamedov, F.; Lindblad, A.; Johansson, F.O.; Chiesa, M.; Sá, J.; Palmisano, G. Long-Lasting Non-hydrogenated Dark Titanium Dioxide: Medium Vacuum Anneal for Enhanced Visible Activity of Modified Multiphase Photocatalysts. ChemCatChem 2018, 10, 2949-2954. [CrossRef]

49. Nair, V.; Muñoz-Batista, M.J.; Fernández-García, M.; Luque, R.; Colmenares, J.C. Thermo-Photocatalysis: Environmental and Energy Applications. ChemSusChem 2019, 12, 2098-2116. [CrossRef]

50. Ibrahim, A.; Othman, M.Y.; Ruslan, M.H.; Mat, S.; Sopian, K. Recent advances in flat plate photovoltaic/thermal (PV/T) solar collectors. Renew. Sustain. Energy Rev. 2011, 15, 352-365. [CrossRef]

51. Cox Iii, C.; Raghuraman, P. Design considerations for flat-plate-photovoltaic/thermal collectors. Sol. Energy 1985, 35, 227-241. [CrossRef]

52. Coventry, J.S. Performance of a concentrating photovoltaic/thermal solar collector. Sol. Energy 2005, 78, 211-222. [CrossRef]

53. Daneshazarian, R.; Cuce, E.; Cuce, P.M.; Sher, F. Concentrating photovoltaic thermal (CPVT) collectors and systems: Theory, performance assessment and applications. Renew. Sustain. Energy Rev. 2018, 81, 473-492. [CrossRef]

54. Widyolar, B.; Jiang, L.; Brinkley, J.; Hota, S.K.; Ferry, J.; Diaz, G.; Winston, R. Experimental performance of an ultra-low-cost solar photovoltaic-thermal (PVT) collector using aluminum minichannels and nonimaging optics. Appl. Energy 2020, $268,114894$. [CrossRef]

55. ALTA DEVICES Technolgy Brief: Single Solar Cell; Alta Devices: Sunnyvale, CA, USA, 2014; Available online: http://dukeofdrones. com/wp-content/uploads/2015/02/single_cell.pdf (accessed on 29 December 2020).

56. Panasonic. Photovoltaic Module HIT VBHN3-series Datasheet. Available online: https://panasonic.net/lifesolutions/solar/ download/pdf/N330_325_320SJ47Datasheet_190226.pdf (accessed on 29 December 2020).

57. Johnsen, H.J.; Aksnes, A.; Torgersen, J. Beyond the 2D limit: Étendue-squeezing line-focus solar concentrators. Opt. Lett. 2020, 46, 42-45. [CrossRef]

58. Widyolar, B.; Jiang, L.; Ferry, J.; Winston, R. Non-tracking East-West XCPC solar thermal collector for 200 celsius applications. Appl. Energy 2018, 216, 521-533. [CrossRef]

59. Mittelman, G.; Kribus, A.; Mouchtar, O.; Dayan, A. Water desalination with concentrating photovoltaic/thermal (CPVT) systems. Sol. Energy 2009, 83, 1322-1334. [CrossRef]

60. Brinkley, J.; Jiang, L.; Widyolar, B.; Hota, S.K.; Bhusal, Y.; Diaz, G.; Winston, R. Thermal, electrical, and cost study of advanced optical photovoltaic thermal system (ADOPTS). Appl. Energy 2020, 269, 115105. [CrossRef]

61. Dönitz, W.; Erdle, E. High-temperature electrolysis of water vapor-status of development and perspectives for application. Int. J. Hydrog. Energy 1985, 10, 291-295. [CrossRef] 
62. Doenitz, W.; Schmidberger, R.; Steinheil, E.; Streicher, R. Hydrogen production by high temperature electrolysis of water vapour. Int. J. Hydrog. Energy 1980, 5, 55-63. [CrossRef]

63. Lin, M.; Haussener, S. Techno-economic modeling and optimization of solar-driven high-temperature electrolysis systems. Sol. Energy 2017, 155, 1389-1402. [CrossRef]

64. Parvareh, F.; Sharma, M.; Qadir, A.; Milani, D.; Khalilpour, R.; Chiesa, M.; Abbas, A. Integration of solar energy in coal-fired power plants retrofitted with carbon capture: A review. Renew. Sustain. Energy Rev. 2014, 38, 1029-1044. [CrossRef] 